\title{
The hidden hand of chloride in hypertension
}

\author{
Linsay McCallum • Stefanie Lip • \\ Sandosh Padmanabhan
}

Received: 8 October 2014 /Revised: 3 December 2014 / Accepted: 5 December 2014 / Published online: 27 January 2015

(C) The Author(s) 2015. This article is published with open access at Springerlink.com

\begin{abstract}
Among the environmental factors that affect blood pressure, dietary sodium chloride has been studied the most, and there is general consensus that increased sodium chloride intake increases blood pressure. There is accruing evidence that chloride may have a role in blood pressure regulation which may perhaps be even more important than that of $\mathrm{Na}^{+}$. Though more than $85 \%$ of $\mathrm{Na}^{+}$is consumed as sodium chloride, there is evidence that $\mathrm{Na}^{+}$and $\mathrm{Cl}^{-}$concentrations do not go necessarily hand in hand since they may originate from different sources. Hence, elucidating the role of $\mathrm{Cl}^{-}$as an independent player in blood pressure regulation will have clinical and public health implications in addition to advancing our understanding of electrolyte-mediated blood pressure regulation. In this review, we describe the evidence that support an independent role for $\mathrm{Cl}^{-}$on hypertension and cardiovascular health.
\end{abstract}

Keywords Salt $\cdot$ Chloride $\cdot$ Hypertension $\cdot$ Blood pressure $\cdot$ Anion

Essential hypertension is the result of a complex interplay between multiple regulatory systems which are themselves influenced by a multitude of genetic and environmental factors. Among the environmental factors that affect blood pressure, dietary sodium chloride has been studied the most, and there is general consensus that increased sodium chloride intake increases blood pressure. The role for $\mathrm{NaCl}$ is supported by insights from the pressure-natriuresis mechanism [30], monogenic forms of hypertension [51], and dietary salt reduction studies $[16,32,76]$. However, there is still considerable

L. McCallum · S. Lip · S. Padmanabhan $(\square)$

BHF Glasgow Cardiovascular Research Centre, Institute of

Cardiovascular and Medical Sciences, University of Glasgow,

Glasgow G12 8TA, UK

e-mail: sandosh.padmanabhan@glasgow.ac.uk debate about $\mathrm{NaCl}$ and hypertension particularly in relation to the context in which this occurs, its prognostic implications, and the role of the underlying regulatory and counterregulatory pathways that are perturbed when salt intake is altered $[2,25,43,60,62,65-67]$. The blood pressure response to sodium chloride intake is referred to as salt sensitivity and while this has universal definition, a 5-10\% change in office blood pressure in response to a change in salt intake is indicative. Importantly, studies of salt sensitivity show that the blood pressure responses to salt are variable and demonstrate a Gaussian distribution within populations. Salt sensitivity is more prevalent in hypertensive individuals (30-50 \%) compared to normotensives, and the presence of salt sensitivity in normotensives is a risk factor for future development of hypertension [95]. Salt sensitivity is not specifically $\mathrm{NaCl}$ related, as it can be modulated by other components of the diet including potassium, calcium, protein, carbohydrate, and fat $[45,53]$. There is growing evidence that $\mathrm{Cl}^{-}$component of $\mathrm{NaCl}$ may have a more specific role in salt-sensitive blood pressure, and this may perhaps be even more important than that of $\mathrm{Na}^{+}$. But this is neither a recent nor novel idea; a role for $\mathrm{Cl}^{-}$had been mooted as early as 1904 by Ambard and Beaujard [3] and in 1908 by Higgins [34] who pointed out that hypertension was intimately associated with "chlorine retention." Then in 1929, Berghoff and Geraci [5] noted that loading hypertensive individuals with sodium bicarbonate did not have the same pressor effect as loading with sodium chloride. Since then, an independent effect of $\mathrm{Cl}^{-}$has been rediscovered in the 80 s using diet containing citrate or phosphate as the anion for $\mathrm{Na}^{+}[48,49,83,97]$, and again more recently from epidemiologic outcome studies showing contrasting associations of serum $\mathrm{Cl}^{-}$and $\mathrm{Na}^{+}$on mortality [19, 59]. In usual diets, more than $85 \%$ of $\mathrm{Na}^{+}$is consumed as sodium chloride and any clinical relevance of the independent effect of $\mathrm{Cl}^{-}$on blood pressure and prognosis has been considered to be largely "academic" [39]. However, studies 
measuring $\mathrm{Na}^{+}$and $\mathrm{Cl}^{-}$content in processed foods indicate that $\mathrm{Na}^{+}$and $\mathrm{Cl}^{-}$concentrations do not go necessarily hand in hand since they may originate from different sources [13]. In this review, we shall describe the role of $\mathrm{Cl}^{-}$as a significant electrolyte in its own right with major impact on hypertension and health.

\section{Dietary chloride and blood pressure — animal and human studies}

There is data from three experimental rat models (Dahl saltsensitive rat, DOCA salt-sensitive rat, and SHRSP) demonstrating that the full expression of NaCl-dependent hypertension is reliant on the concomitant provision of both $\mathrm{Na}^{+}$and $\mathrm{Cl}^{-}$. Early studies in Dahl salt-sensitive rats $[1,44,46]$ showed that hypertension occurred within several weeks when animals were fed on a high $\mathrm{NaCl}$ diet, but not when the animals were fed an identical $\mathrm{Na}^{+}$load provided as sodium bicarbonate or other non-chloride salts of $\mathrm{Na}^{+}$. Kurtz and Morris [49] showed similar findings in a model of desoxycorticosterone acetate (DOCA) salt-sensitive hypertension where after administration of DOC, the mean systolic blood pressure in rats given sodium chloride were significantly higher than in those given sodium bicarbonate and/or sodium ascorbate. The failure of selective dietary sodium loading to produce hypertension was not related to differences of body weight, net $\mathrm{Na}^{+}$ balance, blood $\mathrm{pH}$, serum concentrations of $\mathrm{Na}^{+}$, potassium, or chloride [1, 44, 46, 49]. Passmore and Jiminez [73] showed that in DOCA salt-sensitive hypertensive rats, blood pressure and renal vascular resistance were significantly higher in rats consuming a diet high in $\mathrm{Cl}^{-}$while cardiac output was related to $\mathrm{Na}^{+}$intake. Their group followed this with studies showing that the pressure-flow curves of the DOCA-high $\mathrm{Cl}^{-}$groups shifted significantly downward (reduced renal blood flow at all pressures) and rightward (elevated lower threshold) compared with the DOCA-normal $\mathrm{NaCl}$ and -high $\mathrm{Na}^{+}$groups [37]. Luft et al. [54] reported that supplementation of $\mathrm{NaCl}$ in drinking water caused a modest but significant increase of arterial pressure in the stroke-prone spontaneously hypertensive rat (SHRSP), whereas an equivalent $\mathrm{Na}^{+}$load, primarily in the form of sodium bicarbonate, did not. The increase in blood pressure with $\mathrm{Cl}^{-}$alone was less than the increase with $\mathrm{NaCl}$ in both Dahl salt-sensitive rat and SHRSP, suggesting that the pressor "sensitivity" to dietary $\mathrm{NaCl}$ depends on both its $\mathrm{Na}^{+}$and $\mathrm{Cl}^{-}$components [96, 100]. Schmidlin et al. [77] and Tanaka et al. [89] in a study of SHRSP showed that dietary $\mathrm{Cl}^{-}$was selectively sufficient to induce a pressor effect and that the $\mathrm{Na}^{+}$component of dietary $\mathrm{NaCl}$ was not selectively sufficient to induce a pressor effect. Further support for the role of $\mathrm{Cl}^{-}$comes from the renin response to $\mathrm{Na}^{+}$and $\mathrm{Cl}^{-}$. The rise in blood pressure with $\mathrm{NaCl}$ intake is usually accompanied by suppression of the renin-angiotensin system and decreased plasma renin. Acute and chronic administration of non-chloride sodium salts did not appear to suppress plasma renin activity in rats, while renin was inhibited by both sodium chloride and by selective $\mathrm{Cl}^{-}$(without $\mathrm{Na}^{+}$) loading both in rats and humans $[1,38,44,46]$. Curiously, a diet containing a combination of sodium iodide and sodium bromide induces hypertension more readily than other non-chloride sodium salts in DOCA-treated rats, suggesting that the role of $\mathrm{Cl}^{-}$in the effect of $\mathrm{NaCl}$ on blood pressure may be related to some property common to halides [7].

A limited number of clinical observations also suggest that blood pressure is not increased in humans by high dietary $\mathrm{Na}^{+}$ intake in the absence of $\mathrm{Cl}^{-}$. The earliest clinical study in 1929 showed that $\mathrm{Cl}^{-}$was the main blood pressure increasing component with the observation that sodium bicarbonate did not have the same pressor effect as sodium chloride in hypertensive individuals [5]. Kurtz et al. [48] demonstrated that the rise in blood pressure in response to a high sodium diet (highsalt diet, $240 \mathrm{mmol}$ sodium chloride per day; $5.52 \mathrm{~g} \mathrm{Na}^{+}$) was abolished upon substituting an equimolar amount of sodium citrate. Luft et al. [55] showed opposite effects of $\mathrm{NaCl}$ and $\mathrm{NaHCO}_{3}$ on blood pressure and calcium excretion with $\mathrm{NaHCO}_{3}$ reducing blood pressure but increasing calcium excretion. Shore et al. [83] reported that $\mathrm{NaCl}$ intake induced a greater rise in blood pressure than sodium phosphate intake. In 1945, Grollman showed that both $\mathrm{Na}^{+}$and $\mathrm{Cl}^{-}$were required to increase blood pressure in humans when dietary supplementation with ammonium chloride failed to increase blood pressure of hypertensive humans after dietary $\mathrm{NaCl}$ restriction had decreased blood pressure [28]. Also, in hypertensive humans, the reduction of blood pressure by dietary potassium was attenuated by potassium chloride compared with that of potassium citrate [71], but this difference was not observed in other studies [8,33], and supplemental potassium chloride did not reduce the need for antihypertensive medication in hypertensive men on a restricted-sodium diet [27].

\section{Serum chloride and outcomes}

Large epidemiologic studies curiously show that lower circulating levels of $\mathrm{Cl}^{-}$are associated with higher cardiovascular and all-cause mortality. De Bacquer et al. [19] studied 9106 participants from the Belgian Interuniversity Research on Nutrition and Health (BIRNH) study who were followed up for 10 years. They showed serum $\mathrm{Cl}^{-}<100 \mathrm{mEq} / \mathrm{L}$ was associated with an increased risk of all-cause, cardiovascular disease, non-cardiovascular disease, and coronary heart disease mortality after adjustment for age, body mass index (BMI), and serum $\mathrm{Na}^{+}$levels. Serum $\mathrm{Cl}^{-}<100 \mathrm{mmol} / \mathrm{L}$ was found to be a strong predictor (RR 1.77; $95 \%$ CI 1.22-2.5), in multivariate analysis, of total, cardiovascular, and non- 
cardiovascular mortality independent of other classic risk factors and larger than the effects of diabetes (RR 1.46; $95 \%$ CI 0.81-2.63), smoking status (RR 1.50; $95 \%$ CI 1.10-2.05), BMI (RR 1.20; $95 \%$ CI 0.85-1.67), and cholesterol levels (RR 1.16; $95 \%$ CI 0.88-1.54).

A post hoc analysis of the Candesartan in Heart failureAssessment of Reduction in Mortality and Morbidity (CHARM) study [21] aimed to identify novel prognostic markers in heart failure in a cohort of 2679 American patients. The multivariate analysis showed that serum $\mathrm{Cl}^{-}$was a predictor of all-cause mortality in patients with heart failure with an adjusted $\mathrm{HR} 0.78$ per SD increase in serum $\mathrm{Cl}^{-}(95 \% \mathrm{CI}$ $0.71-0.85$ ), suggesting that serum $\mathrm{Cl}^{-}$predicts risk independently of blood pressure and serum $\mathrm{Na}^{+}$.

A large study of 12,968 treated hypertensive patients attending the Glasgow Blood Pressure Clinic with a follow up period of 197,101 person-years sought to investigate the association between serum $\mathrm{Cl}^{-}$and mortality [59]. Similar to De Bacquer et al. [19], this study reported that individuals with serum $\mathrm{Cl}^{-}<100 \mathrm{mEq} / \mathrm{L}$ had the lowest survival independent of serum $\mathrm{Na}^{+}$or $\mathrm{HCO}_{3}{ }^{-}$levels $(p<0.001)$. Multivariate, adjusted, analysis showed an inverse association between serum $\mathrm{Cl}^{-}$and all-cause mortality; a $1.5 \%$ reduction in all-cause mortality is seen for every $1 \mathrm{mEq} / \mathrm{L}$ increase in serum $\mathrm{Cl}^{-}$(HR $0.985 ; 95 \%$ CI $0.980-0.990$ ). Similar results were shown for cardiovascular disease mortality (HR 0.985; $95 \%$ CI 0.978 0.991), ischaemic heart disease mortality (HR 0.985; $95 \%$ CI 0.976-0.995), and non-cardiovascular disease mortality (HR $0.985 ; 95 \%$ CI $0.977-0.990)$. The association with stroke mortality did not reach statistical significance (HR 0.996; $95 \%$ CI 0.981-1.010).

The mechanism by which low serum $\mathrm{Cl}^{-}$increases mortality or cardiovascular events is unclear [23]. The risk associated with low serum $\mathrm{Cl}^{-}$appears to be independent of serum $\mathrm{Na}^{+}, \mathrm{K}^{+}$, or anion gap [59]. This also suggests that dietary $\mathrm{Cl}^{-}$and serum $\mathrm{Cl}^{-}$exert different effects and perhaps the regulation of serum $\mathrm{Cl}^{-}$is not entirely related to dietary intake and renal mechanisms. Emerging evidence that the immune system plays an extrarenal regulatory role in $\mathrm{Na}^{+}$homeostasis and the intriguing finding that when this immune mechanism was blocked there was selective $\mathrm{Cl}^{-}$accumulation in the skin salt-sensitive hypertension would support this hypothesis [56, 57, 98].

\section{Chloride physiology}

$\mathrm{Cl}^{-}$is the principal extracellular and intracellular anion in the body representing $70 \%$ of the total negative ion content and about $0.15 \%$ of total body weight (115 g in an adult). The normal plasma concentration of $\mathrm{Na}^{+}$is $135-145 \mathrm{mEq} / \mathrm{L}$. Because of its high concentration, $\mathrm{Cl}^{-}$is critical in maintaining electroneutrality. $\mathrm{Cl}^{-}$is responsible for about 100 of the $300 \mathrm{mOsml} / \mathrm{L}$ of extracellular fluid tonicity [4]. Regulatory mechanisms for volume homeostasis are generally triggered by changes in $\mathrm{Na}^{+}$and $\mathrm{Cl}^{-}$concentrations. $\mathrm{Cl}^{-}$has an inverse relationship with bicarbonate and this maintains acid-base balance through reciprocal transport into and out of erythrocytes and renal tubuli [4]. $\mathrm{Cl}^{-}$excretion is an important mechanism in the kidney's adaptation to metabolic acidosis and chronic respiratory acid-base disturbances. Circulating $\mathrm{Cl}^{-}$concentrations are mainly regulated by the gastrointestinal tract and the kidneys. $\mathrm{Cl}^{-}$is absorbed along the entire length of the intestine, secreted by the gastric parietal cells as $\mathrm{HCl}$. The driving flux for fluid secretion into the intestinal tract is the osmotic gradient between the intestinal lumen and the mucosa which is mainly generated by $\mathrm{Cl}^{-}$and to a lesser extent by $\mathrm{HCO}_{3}{ }^{-}$. Normally, the kidney adapts urinary $\mathrm{Na}^{+}$and $\mathrm{Cl}^{-}$ excretion to match exactly daily dietary $\mathrm{NaCl}$ intake. $\mathrm{Cl}^{-}$ channels are expressed along the entire mammalian nephron and participate in transepithelial $\mathrm{Cl}^{-}$transport, cell volume regulation, and acidification of intracellular vesicles [92]. Renal reabsorption of $\mathrm{Na}^{+}$and $\mathrm{Cl}^{-}$is tightly linked in most segments, often occurring even through the same transport proteins such as the $\mathrm{Na}^{+}-\mathrm{K}^{+}-2 \mathrm{Cl}^{-}$cotransporter $\mathrm{NKCC}_{2}$ or the $\mathrm{Na}^{+}-\mathrm{Cl}^{-}$cotransporter $\mathrm{NCC}$ in the thick ascending limb or the distal tubule, respectively. In the proximal tubule and in parts of the collecting system, the transport of $\mathrm{Cl}^{-}$and $\mathrm{Na}^{+}$is mediated by separate mechanisms and $\mathrm{Cl}^{-}$fluxes occur through both paracellular and transcellular routes. Remarkably, in the connecting tubule (CNT) and the collecting duct (CD), $\mathrm{Na}^{+}$reabsorption is not linked molecularly to $\mathrm{Cl}^{-}$transport directly but appears to be linked to bicarbonate secretion. In the collecting duct, particularly in the CNT and cortical collecting duct (CCD), $\mathrm{Na}^{+}$is reabsorbed via the aldosterone-sensitive luminal epithelial $\mathrm{Na}^{+}$channel $(\mathrm{ENaC})$ and the basolateral $\mathrm{Na}^{+}-\mathrm{K}^{+}$-ATPase in principal cells. However, these cells appear to have almost no $\mathrm{Cl}^{-}$conductance on both membranes, excluding them as the route for transcellular $\mathrm{Cl}^{-}$transport. In contrast, neighboring intercalated cells express a number of anion transport and anion channel proteins. The $\mathrm{Na}^{+}$-independent $\mathrm{Cl}^{-} / \mathrm{HCO}_{3}{ }^{-}$exchanger, pendrin (SLC26A4), is located on the apical membrane of B-intercalated cells in the kidney DCT, CCD, and the CNT and mediates the secretion of $\mathrm{HCO}_{3}{ }^{-}$and the reabsorption of $\mathrm{Cl}^{-}$. Type A intercalated cells in contrast express the $\mathrm{H}^{+}$ATPase on the apical plasma membrane and the $\mathrm{Cl}^{-} / \mathrm{HCO}_{3}{ }^{-}$ exchanger (AE1) on the basolateral plasma membrane. Pendrin may be regulated by the urinary excretion of $\mathrm{Cl}^{-}$. With depleted urinary $\mathrm{Cl}^{-}$, pendrin is upregulated and when large amounts of $\mathrm{Cl}^{-}$are delivered to the CCT, the expression of pendrin is reduced $[12,93]$. The basolaterally expressed $\mathrm{Cl}^{-} / \mathrm{HCO}^{-}$anion exchanger, AE1, that releases bicarbonate into blood belongs to a subfamily of electroneutral anion exchangers of the SLC4 family of bicarbonate transporters. 
AE1 is abundant in the red cell membrane, where it is an integral part of the cell's cytoskeleton where it has a key role in the normal gas transfer of $\mathrm{CO}_{2}$. It is also expressed in the basolateral membrane of the collecting duct acid-secreting cell, though as a shorter $\mathrm{N}$-terminally truncated form (kAE1), where it transports intracellular $\mathrm{HCO}^{-}$out of the cell in exchange for Cl-. Mutations in AE1 cause distal renal tubular acidosis, hereditary spherocytosis, and Southeast Asian ovalocytosis [86, 99].

The intracellular concentration of $\mathrm{Cl}^{-}$is much lower than its plasma concentration and depends on the resting membrane potential of the cell and ranges from $2-4 \mathrm{mEq} / \mathrm{L}$ in muscle cells and $100-120 \mathrm{mEq} / \mathrm{L}$ in smooth muscle cells and red blood cells $[4,29]$. The $\mathrm{Cl}^{-}$channels in other tissues include (1) the $\mathrm{ClC}$ family of $\mathrm{Cl}^{-}$channels that are often voltage-gated, (2) the cystic fibrosis transmembrane conductance regulator (CFTR), a member of the $\mathrm{ABC}$ transporter family, (3) the ligand-gated GABA and glycine-activated $\mathrm{Cl}^{-}$ channels, (4) the calcium-activated $\mathrm{Cl}^{-}$channels and bestrophins, and (5) the transmembrane protein 16 (TMEM16)/anoctamin (ANO) [20, 92].

\section{Chloride, blood pressure, and cardiovascular risk-putative mechanisms}

A direct role for $\mathrm{Cl}^{-}$on hypertension is not established currently. However, evidence from monogenic syndromes, dietary and animal studies on renal $\mathrm{Cl}^{-}$balance, and $\mathrm{Cl}^{-}$transporters in vascular tissues point to a critical role for $\mathrm{Cl}^{-}$in mechanisms that contribute to blood pressure regulation.

Monogenic syndromes associated with $\mathrm{Cl}^{-}$transporters manifest high and low blood pressure phenotypes. In Gordon's syndrome (pseudohypoaldosteronism type II), hypertension occurs as a consequence of increased $\mathrm{Cl}^{-}$reabsorption in the thiazide-sensitive segment of the distal renal tubule [87]. Bartter syndrome is associated with salt wasting, hypokalemia, metabolic alkalosis, and increased renin secretion and is caused by inactivating mutations in genes encoding ion channels and transporters that mediate salt transport in the thick ascending limb of the loop of Henle [6]. The genes implicated in Bartter's syndrome are the NKCC2, the potassium channel (ROMK), one of the $\mathrm{Cl}^{-}$channels (CIC-Ka), and barttin (an essential subunit for the $\mathrm{Cl}^{-}$channels CIC-Ka and $\mathrm{CIC}-\mathrm{Kb}$ ).

Extensive investigations in several models of hypertensive rats and in humans show that loading with equimolar amounts of sodium salts causes similar degrees of $\mathrm{Na}^{+}$retention, weight gain, and suppression of RAAS, but only sodium chloride causes an expansion of plasma volume and a rise in BP [7]. In Dahl-S rats, DOCA salt rats, and in humans, plasma volume is higher on a high $\mathrm{NaCl}$ intake than when $\mathrm{Na}^{+}$is provided with anions other than $\mathrm{Cl}^{-}$, although net $\mathrm{Na}^{+}$ balances do not differ. This suggests that the anion ingested with $\mathrm{Na}^{+}$affects the distribution of $\mathrm{Na}^{+}$between the intracellular and extracellular compartments [7].

$\mathrm{Cl}^{-}$reabsorption in the cortical segment of the loop of Henle is greater in Dahl-S than in Dahl salt-resistant (R) rats when both are examined at equivalent renal perfusion pressures [40]. This finding is present before exposure to a high $\mathrm{NaCl}$ diet and before the onset of hypertension. Enhanced reabsorption of water and $\mathrm{Cl}^{-}$in the loop of Henle may contribute to the blunted natriuretic capacity and hence to hypertension in Dahl-S rats. In the Dahl-S rat, if $\mathrm{Cl}^{-}$delivery to the loop is related to dietary $\mathrm{Cl}^{-}$intake, decreased renal tubular reabsorption of $\mathrm{Cl}^{-}$may account for the failure of nonchloride salts of $\mathrm{Na}^{+}$to increase blood pressure [42].

In vivo, in isolated perfused kidneys, and in kidneys perfused in situ, hyperchloremia results in renal vasoconstriction and a decline in glomerular filtration rate as a consequence of tubuloglomerular feedback [77, 78]. This suggest that tubuloglomerular feedback is activated by increased $\mathrm{Cl}^{-}$delivery to the macula densa in chloride-fed animals, resulting in increased renal afferent arteriolar resistance, reduced renal blood flow and glomerular filtration rate, and increased systemic arterial pressure.

In clinical studies, the failure of blood pressure to fall significantly during the non-chloride $\mathrm{Na}^{+}$salt phase may reflect the fact that the enrolled subjects in most of these studies were primarily salt-sensitive. A high dietary sodium chloride intake has been shown to increase the pressor response to both norepinephrine [75] and angiotensin II [36] and thus contribute to salt sensitivity. However, Sharma et al. [81] showed that the pressor response to norepinephrine and angiotensin II is dependent on $\mathrm{Na}^{+}$but not on $\mathrm{Cl}^{-}$, and this finding in conjunction with the observation that blood pressure increased with $\mathrm{NaCl}$ but not with non-halide $\mathrm{Na}^{+}$would suggest that enhanced pressor response is not the sole mechanism responsible for salt sensitivity $[81,82]$.

The regulation of release and synthesis of renin by the juxtaglomerular cells in response to body salt content is multifactorial and involves angiotensin II, autacoids released from endothelial or macula densa (MD) cells, various hormones, and the intraluminal blood pressure in afferent arterioles [47]. The MD mechanism for control of renin secretion is through tubular salt sensing, and a reduced $\mathrm{NaCl}$ concentration in the macula densa segment of the nephron elicits an activation of the renin-angiotensin system. There is ample evidence that the MD cells senses luminal $\mathrm{NaCl}$ concentration via the $\mathrm{NKCC} 2$ cotransporter and that a reduction in $\mathrm{NaCl}$ concentration results in stimulation of renin release and renin synthesis [69, 84]. There is considerable evidence that renin release is inhibited by increased $\mathrm{Cl}^{-}$delivery to the macula densa or increased $\mathrm{Cl}^{-}$transport across the thick ascending limb of the loop of Henle $[52,80] . \mathrm{Cl}^{-}$dependence has been related to the involvement of $\mathrm{NKCC} 2$ in the initiation of a transmitted MD 
signal, and the relative affinities of NKCC2 for $\mathrm{Na}^{+}$and $\mathrm{Cl}^{-}$ are such that the $\mathrm{Cl}^{-}$ion is predicted to act as the dominant physiological regulator of $\mathrm{NKCC} 2$ transport rate, and this mechanism is virtually inoperative when luminal $\mathrm{Cl}^{-}$is low $[10,26,79]$. In studies of uromodulin knock-out mice, Mutig et al. [63] showed that activation of NKCC2 is facilitated by uromodulin in a $\mathrm{Cl}^{-}$-sensitive manner, which is interesting as there is now an accrual of data from human genome-wide association studies and rodent studies that uromodulin is associated with hypertension and salt sensitivity [24, 72, 90]. The release of prostaglandin E2 from the macula densa and the adjacent thick ascending limb of Henle's loop increases when the concentration of sodium chloride in the tubular fluid falls $[74,103]$. Such a fall in tubular $\mathrm{NaCl}$ concentration at the macula densa site is thought to occur in states of salt deficiency and in situations of reduced glomerular filtration. The data from salt-restricted humans does not show difference in renin and angiotensin II production with $\mathrm{NaCl}$ and non-halide $\mathrm{Na}^{+}$ dietary intake $[22,48,55,81-83]$, while the phenomenon is not as consistently observed in rodents and may suggest species differences in BP regulation [46, 52].

Several early studies demonstrated $\mathrm{Cl}^{-}$flux in a variety of different vascular smooth muscle cell (SMC) types. Noradrenaline stimulated $\mathrm{Cl}^{-}$efflux in rat aorta [85] and rabbit pulmonary veins [14]. Endothelin activates $\mathrm{Cl}^{-}$currents in porcine coronary artery, human mesenteric artery SMCs, [41], and cultured aortic SMCs [91]. Studies using nonselective $\mathrm{Cl}^{-}$channel antagonists $[64,88]$ and anion replacement $[17,50,94]$ support the concept that $\mathrm{Cl}^{-}$flux contributes to vasoconstriction. 4,4'-Diisothiocyanatostilbene-2,2'-disulfonic acid (DIDS) and indaryloxyacetic acid (IAA-94) hyperpolarized and relaxed pressurized rat cerebral arteries [64]. IAA-94 inhibited ET-induced vasoconstriction in cultured vascular SMCs [88]. Lowering extracellular $\mathrm{Cl}^{-}$potentiated pressure-induced constriction in rat cerebral arteries [64]. In addition to modulating SMC contractility, both volume-sensitive $\mathrm{Cl}^{-}$channels and $\mathrm{Ca}^{2+}$-activated $\mathrm{Cl}^{-}$channels have been proposed to control SMC proliferation [15, 101]. ClC-3 has been found to be ubiquitously expressed in almost all eukaryotic cells, which functions as anion channel at cell plasma membrane or as $\mathrm{Cl}^{-} / \mathrm{H}^{+}$antiporter in intracellular vesicles. Studies in vascular smooth muscle cell showed that several cytokines, including tumor necrosis factor- $\alpha$ $(\mathrm{TNF} \alpha)$ and interleukin $1 \beta$, could activate $\mathrm{Cl}^{-}$conductance, and this $\mathrm{Cl}^{-}$current is dependent on ClC-3 expression [58]. ClC-3-dependent $\mathrm{Cl}^{-}$efflux decreased intracellular $\mathrm{Cl}^{-}$, which underlies the proinflammatory effects of ClC-3-dependent $\mathrm{Cl}^{-}$ conductance by activating the NF-KB pathway $[61,102]$.

The ubiquitous $\mathrm{Na}^{+}, \mathrm{K}^{+}, 2 \mathrm{Cl}^{-}$cotransporter (NKCC1) belongs to the superfamily of $\mathrm{Cl}^{-}$-coupled carriers and are inhibited by high-ceiling diuretics such as furosemide and bumetanide. In the VSMC, loop diuretics decrease the concentration of intracellular chloride, hyperpolarize the sarcolemma, and attenuate $\mathrm{Ca}^{2+}$ influx though voltage-gated channels, indicating a putative mechanism by which NKCC1 contributes to hypertension via elevation of vascular tone [68, 70]. NKCC1-null mice have decreased baseline BP but exhibit augmented BP increment evoked by high-salt diets. NKCC1 deficiency causes approximately threefold elevation in plasma renin concentrations and attenuates high-ceiling diuretics-induced renin production $[68,70]$.

There is evidence of extrarenal regulatory mechanisms for electrolyte homeostasis with the finding of $\mathrm{Na}^{+}$and $\mathrm{Cl}^{-}$sequestration in the skin interstitium which appear to be regulated by the mononuclear phagocyte system [56, 57, 98]. Macrophages infiltrate to the sites of $\mathrm{Na}^{+}$and $\mathrm{Cl}^{-}$overload in the skin which display a hypertonic microenvironment and subsequently upregulate the transcription factor nuclear factor of activated T cells 5 (NFAT5) [31]. The induction of NFAT5 in macrophages of the skin was shown to directly govern the expression of vascular endothelial growth factor C (VEGF-C), resulting in the hyperplasia of lymph capillaries via and interaction with the VEGF receptor 3 (VEGFR3) [98]. Failure of this local extrarenal macrophage-dependent control mechanism to regulate interstitial electrolyte and water homeostasis resulted in arterial hypertension and massive disturbances in skin electrolyte composition [98]. Moreover, when NFAT5/ VEGF-C axis was knocked out in experimental models, there was selective $\mathrm{Cl}^{-}$accumulation in the skin, a direct correlation between skin $\mathrm{Cl}^{-}$content and blood pressure increases, and no relationship between $\mathrm{Na}^{+}$and water content and blood pressure [98].

The paradoxical association of serum $\mathrm{Cl}^{-}$on mortality and the association of dietary $\mathrm{Cl}^{-}$with blood pressure are intriguing and may help attempts to understand the role of $\mathrm{Cl}^{-}$ currents and osmolarity/volume homeostatic mechanisms. Gasowski and Cwynar [23] hypothesize that low serum $\mathrm{Cl}^{-}$, whether associated with a hypoosmotic state or not, may facilitate $\mathrm{Cl}^{-}$currents, acting as an enhancer to the phenomena that have been traced as possible triggers increasing the probability of an open state of these channels. Such phenomena include ischemia-induced local hypoosmotic state leading, in turn, to swelling of the cell and stimulation by tumor necrosis factor- $\alpha$ and interleukin- $1 \beta$ [18, 23, 35, 102]. Experimental evidence support the potential role of several $\mathrm{Cl}^{-}$channels in the heart including CFTR, ClC-2, ClC-3, CLCA, Bestrophin, and TMEM16A which may contribute to cardiac arrhythmogenesis, myocardial hypertrophy and heart failure, and cardioprotection against ischemia-reperfusion [20]. Other potential mechanisms may relate to non-cardiac and non-renal roles for $\mathrm{Cl}^{-}$. For examples, $\mathrm{Cl}^{-}$channels are present in the surface and transverse tubular membranes of mammalian skeletal muscle and $\mathrm{Cl}^{-}$moves into muscle during t-tubular action potentials or with $\mathrm{K}^{+}$-induced depolarization of the sarcolemma. Extracellular $\mathrm{Cl}^{-}$has been shown to be protective against fatigue (with implications for survival and 
cardiovascular risk) involving high-intensity contractions in both fast- and slow-twitch mammalian muscle possibly by preventing excessive depolarisation with exercise-induced decline in trans-sarcolemmal $\mathrm{K}^{+}$gradient $[9,11]$.

In conclusion, $\mathrm{Cl}^{-}$-dependent mechanisms appear to underlie a plethora of critical pathways underlying cardiovascular disease and blood pressure regulation highlighting the need for further studies to elucidate the mechanistic underpinnings of these observations. However, the relationship between dietary chloride, serum chloride, and intracellular chloride all appear to have different pathophysiological effects, and further studies are needed to determine the mechanistic underpinnings of the epidemiologic findings. The weight of evidence indicate that it is time $\mathrm{Cl}^{-}$moved out the shadow of $\mathrm{Na}^{+}$as a mediator of disease and survival.

Acknowledgements This work is supported by a BHF Clinical Research Training Fellowship FS/14/52/30901 (LM, SP).

Open Access This article is distributed under the terms of the Creative Commons Attribution License which permits any use, distribution, and reproduction in any medium, provided the original author(s) and the source are credited.

\section{References}

1. Abboud HE, Luke RG, Galla JH, Kotchen TA (1979) Stimulation of renin by acute selective chloride depletion in the rat. Circ Res 44(6): 815-821

2. Alderman MH, Cohen HW (2012) Dietary sodium intake and cardiovascular mortality: controversy resolved? Am J Hypertens 25(7):727-734

3. Ambard L, Beaujard E (1904) Causes de l'hypertension arterielle. Arch Gen Med 1:520-533

4. Berend K, van Hulsteijn LH, Gans RO (2012) Chloride: the queen of electrolytes? Eur J Intern Med 23(3):203-211

5. Berghoff RS, Geraci AS (1929) The influence of sodium chloride on blood pressure. BMJ 56:395-397

6. Bichet DG, Fujiwara TM (2004) Reabsorption of sodium chloridelessons from the chloride channels. N Engl J Med 350(13):1281-1283

7. Boegehold MA, Kotchen TA (1991) Importance of dietary chloride for salt sensitivity of blood pressure. Hypertension $17(1$ Suppl): I158-I161

8. Braschi A, Naismith DJ (2008) The effect of a dietary supplement of potassium chloride or potassium citrate on blood pressure in predominantly normotensive volunteers. Br J Nutr 99(6):1284-1292

9. Bretag AH (1987) Muscle chloride channels. Physiol Rev 67(2): 618-724

10. Briggs JP, Schnermann JB (1996) Whys and wherefores of juxtaglomerular apparatus function. Kidney Int 49(6):1724-1726

11. Cairns SP, Ruzhynsky V, Renaud JM (2004) Protective role of extracellular chloride in fatigue of isolated mammalian skeletal muscle. Am J Physiol Cell Physiol 287(3):C762-C770

12. Capasso G, Rizzo M, Garavaglia ML, Trepiccione F, Zacchia M, Mugione A, Ferrari P, Paulmichl M, Lang F, Loffing J, Carrel M, Damiano S, Wagner CA, Bianchi G, Meyer G (2008) Upregulation of apical sodium-chloride cotransporter and basolateral chloride channels is responsible for the maintenance of salt-sensitive hypertension. Am J Physiol Renal Physiol 295(2):F556-F567
13. Capuano E, van der Veer G, Verheijen PJJ, Heenan SP, van de Laak LFJ, Koopmans HBM, van Ruth SM (2013) Comparison of a sodium-based and a chloride-based approach for the determination of sodium chloride content of processed foods in the Netherlands. $\mathrm{J}$ Food Compos Anal 31(1):129-136

14. Casteels R, Kitamura K, Kuriyama H, Suzuki H (1977) The membrane properties of the smooth muscle cells of the rabbit main pulmonary artery. J Physiol 271(1):41-61

15. Cheng G, Kim MJ, Jia G, Agrawal DK (2007) Involvement of chloride channels in IGF-I-induced proliferation of porcine arterial smooth muscle cells. Cardiovasc Res 73(1):198-207

16. Cook NR, Cutler JA, Obarzanek E, Buring JE, Rexrode KM, Kumanyika SK, Appel LJ, Whelton PK (2007) Long term effects of dietary sodium reduction on cardiovascular disease outcomes: observational follow-up of the trials of hypertension prevention (TOHP). BMJ 334(7599):885-888

17. Dai Y, Zhang JH (2002) Manipulation of chloride flux affects histamine-induced contraction in rabbit basilar artery. Am J Physiol Heart Circ Physiol 282(4):H1427-H1436

18. De Mello WC (2009) Cell swelling, impulse conduction, and cardiac arrhythmias in the failing heart. Opposite effects of angiotensin II and angiotensin (1-7) on cell volume regulation. Mol Cell Biochem 330(1-2):211-217

19. De Bacquer D, De Backer G, De Buyzere M, Kornitzer M (1998) Is low serum chloride level a risk factor for cardiovascular mortality? J Cardiovasc Risk 5(3):177-184

20. Duan D (2009) Phenomics of cardiac chloride channels: the systematic study of chloride channel function in the heart. J Physiol 587(Pt 10):2163-2177

21. Felker GM, Allen LA, Pocock SJ, Shaw LK, McMurray JJ, Pfeffer MA, Swedberg K, Wang D, Yusuf S, Michelson EL, Granger CB (2007) Red cell distribution width as a novel prognostic marker in heart failure: data from the CHARM Program and the Duke Databank. J Am Coll Cardiol 50(1):40-47

22. Ganry O, Boudet J, Wargon C, Hornych A, Meyer P (1993) Effect of sodium bicarbonate and sodium chloride on arterial blood pressure, plasma renin activity and urinary prostaglandins in healthy volunteers. J Hypertens Suppl 11(5):S202-S203

23. Gasowski J, Cwynar M (2013) There is more to salt than just a pinch of sodium. Hypertension 62(5):829-830

24. Graham LA, Padmanabhan S, Fraser NJ, Kumar S, Bates JM, Raffi HS, Welsh P, Beattie W, Hao S, Leh S, Hultstrom M, Ferreri NR, Dominiczak AF, Graham D, McBride MW (2014) Validation of uromodulin as a candidate gene for human essential hypertension. Hypertension 63(3):551-558

25. Graudal NA, Hubeck-Graudal T, Jurgens G (2012) Effects of lowsodium diet vs. high-sodium diet on blood pressure, renin, aldosterone, catecholamines, cholesterol, and triglyceride (Cochrane Review). Am J Hypertens 25(1):1-15

26. Greger R (1985) Ion transport mechanisms in thick ascending limb of Henle's loop of mammalian nephron. Physiol Rev 65(3):760-797

27. Grimm RH Jr, Neaton JD, Elmer PJ, Svendsen KH, Levin J, Segal M, Holland L, Witte LJ, Clearman DR, Kofron P (1990) The influence of oral potassium chloride on blood pressure in hypertensive men on a low-sodium diet. N Engl J Med 322(9):569-574

28. Grollman A, Harrison TR, Masan MF, Baxter J, Crampton J, Riechman F (1945) Sodium restriction in the diet for hypertension. JAMA 129:533-537

29. Gunn RB, Dalmark M, Tosteson DC, Wieth JO (1973) Characteristics of chloride transport in human red blood cells. J Gen Physiol 61(2):185-206

30. Guyton AC (1991) Blood pressure control - special role of the kidneys and body fluids. Science 252(5014):1813-1816

31. Halterman JA, Kwon HM, Wamhoff BR (2012) Tonicityindependent regulation of the osmosensitive transcription factor TonEBP (NFAT5). Am J Physiol Cell Physiol 302(1):C1-C8 
32. He FJ, MacGregor GA (2002) Effect of modest salt reduction on blood pressure: a meta-analysis of randomized trials. Implications for public health. J Hum Hypertens 16(11):761-770

33. He FJ, Marciniak M, Carney C, Markandu ND, Anand V, Fraser WD, Dalton RN, Kaski JC, MacGregor GA (2010) Effects of potassium chloride and potassium bicarbonate on endothelial function, cardiovascular risk factors, and bone turnover in mild hypertensives. Hypertension 55(3):681-688

34. Higgins H (1908) Observations on blood pressure, chlorine retention and dechlorination, hyperacidity, and variation in the starch ration. Lancet 171:1136-1142

35. Hiraoka M, Kawano S, Hirano Y, Furukawa T (1998) Role of cardiac chloride currents in changes in action potential characteristics and arrhythmias. Cardiovasc Res 40(1):23-33

36. Hollenberg NK, Chenitz WR, Adams DF, Williams GH (1974) Reciprocal influence of salt intake on adrenal glomerulosa and renal vascular responses to angiotensin II in normal man. J Clin Investig 54(1):34-42. doi:10.1172/JCI107748

37. Imig JD, Passmore JC, Anderson GL, Jimenez AE (1993) Chloride alters renal blood flow autoregulation in deoxycorticosteronetreated rats. J Lab Clin Med 121(4):608-613

38. Julian BA, Galla JH, Guthrie GP Jr, Kotchen TA (1982) Renin and aldosterone responses to short-term $\mathrm{NaCl}$ or $\mathrm{NaHCO} 3$ loading in man. J Lab Clin Med 100(2):261-268

39. Kaplan's Clinical Hypertension (2010), vol 10. Lippincott Williams \& Wilkins, Philadelphia

40. Kirchner KA (1992) Increased loop chloride uptake precedes hypertension in Dahl salt-sensitive rats. Am J Physiol 262(2 Pt 2): R263-R268

41. Klockner U, Isenberg G (1991) Endothelin depolarizes myocytes from porcine coronary and human mesenteric arteries through a Caactivated chloride current. Pflugers Arch 418(1-2):168-175

42. Kotchen TA (2005) Contributions of sodium and chloride to $\mathrm{NaCl}$ induced hypertension. Hypertension 45(5):849-850

43. Kotchen TA, Cowley AW Jr, Frohlich ED (2013) Salt in health and disease - a delicate balance. N Engl J Med 368(26):2531-2532

44. Kotchen TA, Galla JH, Luke RG (1976) Failure of NaHCO3 and $\mathrm{KHCO} 3$ to inhibit renin in the rat. Am J Physiol 231(4): $1050-1056$

45. Kotchen TA, Kotchen JM (1997) Dietary sodium and blood pressure: interactions with other nutrients. Am J Clin Nutr 65(2 Suppl): 708S-711S

46. Kotchen TA, Luke RG, Ott CE, Galla JH, Whitescarver S (1983) Effect of chloride on renin and blood pressure responses to sodium chloride. Ann Intern Med 98(5 Pt 2):817-822

47. Kurtz A (2012) Control of renin synthesis and secretion. Am J Hypertens 25(8):839-847

48. Kurtz TW, Al-Bander HA, Morris RC Jr (1987) "Salt-sensitive" essential hypertension in men. Is the sodium ion alone important? $\mathrm{N}$ Engl J Med 317(17):1043-1048

49. Kurtz TW, Morris RC Jr (1983) Dietary chloride as a determinant of "sodium-dependent" hypertension. Science 222(4628):1139-1141

50. Lamb FS, Barna TJ (1998) Chloride ion currents contribute functionally to norepinephrine-induced vascular contraction. Am J Physiol 275(1 Pt 2):H151-H160

51. Lifton RP, Gharavi AG, Geller DS (2001) Molecular mechanisms of human hypertension. Cell 104(4):545-556

52. Lorenz JN, Weihprecht H, Schnermann J, Skott O, Briggs JP (1991) Renin release from isolated juxtaglomerular apparatus depends on macula densa chloride transport. Am J Physiol 260(4 Pt 2):F486F493

53. Luft FC, McCarron DA (1991) Heterogeneity of hypertension: the diverse role of electrolyte intake. Annu Rev Med 42:347-355

54. Luft FC, Steinberg H, Ganten U, Meyer D, Gless KH, Lang RE, Fineberg NS, Rascher W, Unger T, Ganten D (1988) Effect of sodium chloride and sodium bicarbonate on blood pressure in stroke-prone spontaneously hypertensive rats. Clin Sci(Lond) 74(6):577-585

55. Luft FC, Zemel MB, Sowers JA, Fineberg NS, Weinberger MH (1990) Sodium bicarbonate and sodium chloride: effects on blood pressure and electrolyte homeostasis in normal and hypertensive man. J Hypertens 8(7):663-670

56. Machnik A, Dahlmann A, Kopp C, Goss J, Wagner H, van Rooijen N, Eckardt KU, Muller DN, Park JK, Luft FC, Kerjaschki D, Titze J (2010) Mononuclear phagocyte system depletion blocks interstitial tonicity-responsive enhancer binding protein/vascular endothelial growth factor $\mathrm{C}$ expression and induces salt-sensitive hypertension in rats. Hypertension 55(3):755-761

57. Machnik A, Neuhofer W, Jantsch J, Dahlmann A, Tammela T, Machura K, Park JK, Beck FX, Muller DN, Derer W, Goss J, Ziomber A, Dietsch P, Wagner H, van Rooijen N, Kurtz A, Hilgers KF, Alitalo K, Eckardt KU, Luft FC, Kerjaschki D, Titze J (2009) Macrophages regulate saltdependent volume and blood pressure by a vascular endothelial growth factor-C-dependent buffering mechanism. Nat Med 15(5):545-552

58. Matsuda JJ, Filali MS, Moreland JG, Miller FJ, Lamb FS (2010) Activation of swelling-activated chloride current by tumor necrosis factor-alpha requires $\mathrm{ClC}$-3-dependent endosomal reactive oxygen production. J Biol Chem 285(30):22864-22873

59. McCallum L, Jeemon P, Hastie CE, Patel RK, Williamson C, Redzuan AM, Dawson J, Sloan W, Muir S, Morrison D, McInnes GT, Freel EM, Walters M, Dominiczak AF, Sattar N, Padmanabhan $\mathrm{S}$ (2013) Serum chloride is an independent predictor of mortality in hypertensive patients. Hypertension 62(5):836-843

60. Mente A, O'Donnell MJ, Rangarajan S, McQueen MJ, Poirier P, Wielgosz A, Morrison H, Li W, Wang X, Di C, Mony P, Devanath A, Rosengren A, Oguz A, Zatonska K, Yusufali AH, LopezJaramillo P, Avezum A, Ismail N, Lanas F, Puoane T, Diaz R, Kelishadi R, Iqbal R, Yusuf R, Chifamba J, Khatib R, Teo K, Yusuf S, Investigators P (2014) Association of urinary sodium and potassium excretion with blood pressure. N Engl J Med 371(7): 601-611. doi:10.1056/NEJMoa1311989

61. Miller FJ Jr, Filali M, Huss GJ, Stanic B, Chamseddine A, Barna TJ, Lamb FS (2007) Cytokine activation of nuclear factor kappa B in vascular smooth muscle cells requires signaling endosomes containing Nox1 and ClC-3. Circ Res 101(7):663-671

62. Mozaffarian D, Fahimi S, Singh GM, Micha R, Khatibzadeh S, Engell RE, Lim S, Danaei G, Ezzati M, Powles J, Global Burden of Diseases N, Chronic Diseases Expert G, (2014) Global sodium consumption and death from cardiovascular causes. N Engl J Med 371(7):624-634. doi:10.1056/NEJMoa1304127

63. Mutig K, Kahl T, Saritas T, Godes M, Persson P, Bates J, Raffi H, Rampoldi L, Uchida S, Hille C, Dosche C, Kumar S, CastanedaBueno M, Gamba G, Bachmann S (2011) Activation of the bumetanide-sensitive $\mathrm{Na}+, \mathrm{K}+, 2 \mathrm{Cl}$ - cotransporter ( $\mathrm{NKCC} 2$ ) is facilitated by Tamm-Horsfall protein in a chloride-sensitive manner. J Biol Chem 286(34):30200-30210

64. Nelson MT, Conway MA, Knot HJ, Brayden JE (1997) Chloride channel blockers inhibit myogenic tone in rat cerebral arteries. J Physiol 502(Pt 2):259-264

65. O'Donnell M, Mente A, Rangarajan S, McQueen MJ, Wang X, Liu L, Yan H, Lee SF, Mony P, Devanath A, Rosengren A, LopezJaramillo P, Diaz R, Avezum A, Lanas F, Yusoff K, Iqbal R, Ilow R, Mohammadifard N, Gulec S, Yusufali AH, Kruger L, Yusuf R, Chifamba J, Kabali C, Dagenais G, Lear SA, Teo K, Yusuf S, Investigators P (2014) Urinary sodium and potassium excretion, mortality, and cardiovascular events. N Engl J Med 371(7):612623. doi:10.1056/NEJMoa1311889

66. O'Donnell MJ, Mente A, Smyth A, Yusuf S (2013) Salt intake and cardiovascular disease: why are the data inconsistent? Eur Heart J 34(14):1034-1040 
67. Oparil S (2014) Low sodium intake - cardiovascular health benefit or risk? N Engl J Med 371(7):677-679

68. Orlov SN, Koltsova SV, Tremblay J, Baskakov MB, Hamet P (2012) NKCC1 and hypertension: role in the regulation of vascular smooth muscle contractions and myogenic tone. Ann Med 44(Suppl 1):S111-S118. doi:10.3109/07853890.2011.653395

69. Orlov SN, Mongin AA (2007) Salt-sensing mechanisms in blood pressure regulation and hypertension. Am J Physiol Heart Circ Physiol 293(4):H2039-H2053. doi:10.1152/ajpheart.00325.2007

70. Orlov SN, Tremblay J, Hamet P (2010) NKCC1 and hypertension: a novel therapeutic target involved in the regulation of vascular tone and renal function. Curr Opin Nephrol Hypertens 19(2):163-168. doi:10.1097/MNH.0b013e3283360a46

71. Overlack A, Maus B, Ruppert M, Lennarz M, Kolloch R, Stumpe KO (1995) Potassium citrate versus potassium chloride in essential hypertension. Effects on hemodynamic, hormonal and metabolic parameters. Dtsch Med Wochenschr 120(18):631-635

72. Padmanabhan S, Melander O, Johnson T, Di Blasio AM, Lee WK, Gentilini D, Hastie CE, Menni C, Monti MC, Delles C, Laing S, Corso B, Navis G, Kwakernaak AJ, Van der HP, Bochud M, Maillard M, Burnier M, Hedner T, Kjeldsen S, Wahlstrand B, Sjogren M, Fava C, Montagnana M, Danese E, Torffvit O, Hedblad B, Snieder H, Connell JM, Brown M, Samani NJ, Farrall M, Cesana G, Mancia G, Signorini S, Grassi G, Eyheramendy S, Wichmann HE, Laan M, Strachan DP, Sever P, Shields DC, Stanton A, Vollenweider P, Teumer A, Volzke H, Rettig R, Newton-Cheh C, Arora P, Zhang F, Soranzo N, Spector TD, Lucas G, Kathiresan S, Siscovick DS, Luan J, Loos RJ, Wareham NJ, Penninx BW, Nolte IM, McBride M, Miller WH, Nicklin SA, Baker AH, Graham D, McDonald RA, Pell JP, Sattar N, Welsh P, Munroe P, Caulfield MJ, Zanchetti A, Dominiczak AF (2010) Genome-wide association study of blood pressure extremes identifies variant near UMOD associated with hypertension. PLoS Genet 6(10):e1001177

73. Passmore JC, Jimenez AE (1990) Separate hemodynamic roles for chloride and sodium in deoxycorticosterone acetate-salt hypertension. Proc Soc Exp Biol Med 194(3):283-288

74. Peti-Peterdi J, Komlosi P, Fuson AL, Guan Y, Schneider A, Qi Z, Redha R, Rosivall L, Breyer MD, Bell PD (2003) Luminal NaCl delivery regulates basolateral PGE2 release from macula densa cells. J Clin Invest 112(1):76-82

75. Rankin LI, Luft FC, Henry DP, Gibbs PS, Weinberger MH (1981) Sodium intake alters the effects of norepinephrine on blood pressure. Hypertension 3(6):650-656

76. Sacks FM, Svetkey LP, Vollmer WM, Appel LJ, Bray GA, Harsha D, Obarzanek E, Conlin PR, Miller ER III, Simons-Morton DG, Karanja N, Lin PH (2001) Effects on blood pressure of reduced dietary sodium and the Dietary Approaches to Stop Hypertension (DASH) diet. DASH-Sodium Collaborative Research Group. N Engl J Med 344(1):3-10

77. Schmidlin O, Tanaka M, Bollen AW, Yi SL, Morris RC Jr (2005) Chloride-dominant salt sensitivity in the stroke-prone spontaneously hypertensive rat. Hypertension 45(5):867-873

78. Schmidlin O, Tanaka M, Sebastian A, Morris RC Jr (2010) Selective chloride loading is pressor in the stroke-prone spontaneously hypertensive rat despite hydrochlorothiazide-induced natriuresis. J Hypertens 28(1):87-94

79. Schnermann J, Briggs J (1982) Concentration-dependent sodium chloride transport as the signal in feedback control of glomerular filtration rate. Kidney Int Suppl 12:S82-S89

80. Schnermann J, Ploth DW, Hermle M (1976) Activation of tubuloglomerular feedback by chloride transport. Pflugers Arch 362(3): 229-240

81. Sharma AM, Schattenfroh S, Thiede HM, Oelkers W, Distler A (1992) Effects of sodium salts on pressor reactivity in salt-sensitive men. Hypertension 19(6 Pt 1):541-548
82. Sharma AM, Schorr U, Oelkers W, Distler A (1993) Effects of sodium salts on plasma renin activity and norepinephrine response to orthostasis in salt-sensitive normotensive subjects. Am J Hypertens 6(9):780-785

83. Shore AC, Markandu ND, MacGregor GA (1988) A randomized crossover study to compare the blood pressure response to sodium loading with and without chloride in patients with essential hypertension. J Hypertens 6(8):613-617

84. Skott O, Briggs JP (1987) Direct demonstration of macula densamediated renin secretion. Science 237(4822):1618-1620

85. Smith JM, Jones AW (1985) Calcium-dependent fluxes of potassium-42 and chloride-36 during norepinephrine activation of rat aorta. Circ Res 56(4):507-516

86. Stehberger PA, Shmukler BE, Stuart-Tilley AK, Peters LL, Alper SL, Wagner CA (2007) Distal renal tubular acidosis in mice lacking the AE1 (band3) Cl. J Am Soc Nephrol 18(5):1408-1418

87. Take C, Ikeda K, Kurasawa T, Kurokawa K (1991) Increased chloride reabsorption as an inherited renal tubular defect in familial type II pseudohypoaldosteronism. N Engl J Med 324(7):472-476

88. Takenaka T, Epstein M, Forster H, Landry DW, Iijima K, Goligorsky MS (1992) Attenuation of endothelin effects by a chloride channel inhibitor, indanyloxyacetic acid. Am J Physiol 262(5 Pt 2):F799-F806

89. Tanaka M, Schmidlin O, Yi SL, Bollen AW, Morris RC Jr (1997) Genetically determined chloride-sensitive hypertension and stroke. Proc Natl Acad Sci U S A 94(26):14748-14752

90. Trudu M, Janas S, Lanzani C, Debaix H, Schaeffer C, Ikehata M, Citterio L, Demaretz S, Trevisani F, Ristagno G, Glaudemans B, Laghmani K, Dell'Antonio G, Loffing J, Rastaldi MP, Manunta P, Devuyst O, Rampoldi L (2013) Common noncoding UMOD gene variants induce salt-sensitive hypertension and kidney damage by increasing uromodulin expression. Nat Med 19(12):1655-1660

91. Van RC, Lazdunski M (1993) Endothelin and vasopressin activate low conductance chloride channels in aortic smooth muscle cells. Pflugers Arch 425(1-2):156-163

92. Veizis IE, Cotton CU (2007) Role of kidney chloride channels in health and disease. Pediatr Nephrol 22(6):770-777

93. Verlander JW, Kim YH, Shin W, Pham TD, Hassell KA, Beierwaltes WH, Green ED, Everett L, Matthews SW, Wall SM (2006) Dietary $\mathrm{Cl}(-)$ restriction upregulates pendrin expression within the apical plasma membrane of type B intercalated cells. Am J Physiol Renal Physiol 291(4):F833-F839

94. Wahlstrom BA, Svennerholm B (1974) Potentiation and inhibition of noradrenaline induced contractions of the rat portal vein in anion substituted solutions. Acta Physiol Scand 92(3):404-411

95. Weinberger MH, Miller JZ, Luft FC, Grim CE, Fineberg NS (1986) Definitions and characteristics of sodium sensitivity and blood pressure resistance. Hypertension 8(6 Pt 2):II127-II134

96. Whitescarver SA, Holtzclaw BJ, Downs JH, Ott CE, Sowers JR, Kotchen TA (1986) Effect of dietary chloride on saltsensitive and renin-dependent hypertension. Hypertension 8(1):56-61

97. Whitescarver SA, Ott CE, Jackson BA, Guthrie GP Jr, Kotchen TA (1984) Salt-sensitive hypertension: contribution of chloride. Science 223(4643):1430-1432

98. Wiig H, Schroder A, Neuhofer W, Jantsch J, Kopp C, Karlsen TV, Boschmann M, Goss J, Bry M, Rakova N, Dahlmann A, Brenner S, Tenstad O, Nurmi H, Mervaala E, Wagner H, Beck FX, Muller DN, Kerjaschki D, Luft FC, Harrison DG, Alitalo K, Titze J (2013) Immune cells control skin lymphatic electrolyte homeostasis and blood pressure. J Clin Invest 123:2803-2815

99. Wu F, Satchwell TJ, Toye AM (2011) Anion exchanger 1 in red blood cells and kidney: Band 3's in a pod. Biochem Cell Biol 89(2): 106-114

100. Wyss JM, Liumsiricharoen M, Sripairojthikoon W, Brown D, Gist R, Oparil S (1987) Exacerbation of hypertension by high chloride, 
moderate sodium diet in the salt-sensitive spontaneously hypertensive rat. Hypertension 9(6 Pt 2):III171-III175

101. Xiao GN, Guan YY, He H (2002) Effects of Cl- channel blockers on endothelin-1-induced proliferation of rat vascular smooth muscle cells. Life Sci 70(19):2233-2241

102. Yang H, Huang LY, Zeng DY, Huang EW, Liang SJ, Tang YB, Su YX, Tao J, Shang F, Wu QQ, Xiong LX, Lv XF, Liu J, Guan YY, Zhou JG (2012) Decrease of intracellular chloride concentration promotes endothelial cell inflammation by activating nuclear factor-kappaB pathway. Hypertension 60(5):12871293

103. Yang T, Park JM, Arend L, Huang Y, Topaloglu R, Pasumarthy A, Praetorius H, Spring K, Briggs JP, Schnermann J (2000) Low chloride stimulation of prostaglandin E2 release and cyclooxygenase- 2 expression in a mouse macula densa cell line. J Biol Chem 275(48):37922-37929 